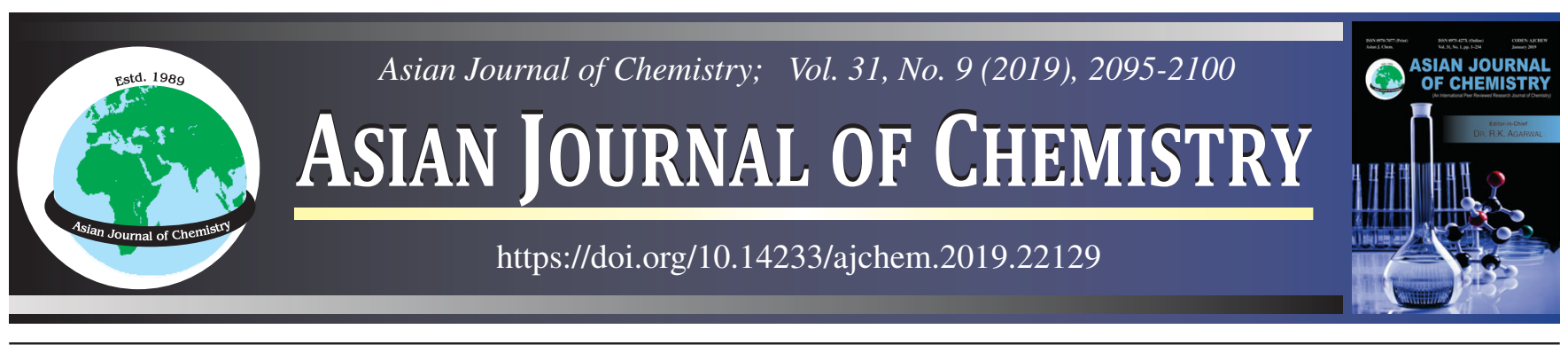

\title{
Synthesis, Spectral Characterization and Biological Evaluation of Schiff Base Metal Complexes Derived from Aniline Derivative
}

\author{
P. PRIYA ${ }^{1}$, S. VEDANAYAKI ${ }^{1, *}$ and P. JAYASEELAN ${ }^{2}$
}

${ }^{1}$ Department of Chemistry, Kandaswami Kandar's College, Namakkal-638182, India

${ }^{2}$ Chemical Division, Mettur Thermal Power Station-2, Mettur Dam-636406, India

*Corresponding author: E-mail: varshuvishal@gmail.com

Received: 10 April 2019;

Accepted: 20 May 2019;

Published online: 31 July 2019;

AJC-19504

$\Gamma$

| A new Schiff base ligand (L) N-(4-fluorophenyl)-1-(4-(((4-fluorophenyl)imino)methyl)phenyl)methaninmine was prepared by the condensation of terephthalaldehyde with 4-fluoroaniline in 1:2 molar ratio. The mononuclear complexes of $\mathrm{Co}(\mathrm{II}), \mathrm{Ni}(\mathrm{II}), \mathrm{Cu}(\mathrm{II}) \mathrm{and}$ $\mathrm{Zn}$ (II) (1-4) have been synthesized in (2:1) ligand to metal ratio. The composition, geometry and binding sites of ligand with metal complexes were evidenced by various spectral methods like molar conductance, elemental analytical data, magnetic measurements, UV| visible, ${ }^{1} \mathrm{H} \&{ }^{13} \mathrm{C}$ NMR, ESI-MS, FT-IR, ESR and thermal analysis. The above studies shows that the ligand is a bidentate and its metal | complexes possess an octahedral geometry. Oxidative cleavage of DNA studies of the complexes were monitored by super helix PUC18DNA using a method of agarose gel electrophoresis. Ligand and its metal complexes were screened against gram positive (Staphylococcus aureus), gram negative (Klebsiella pneumoniae) bacterium and fungus (Candida albicans) strains. Antioxidant activities of the metal complexes possess greater activity than ligand.

Keywords: Schiff Base metal(II) complexes, 4-Fluoroaniline, Octahedral geometry, Antimicrobial activities, DNA cleavage studies.

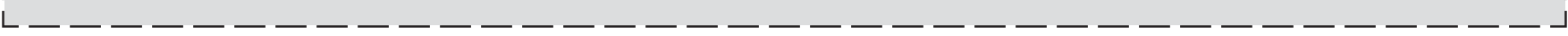

\section{INTRODUCTION}

Substituted aniline derivatives of Schiff base complexes have been extensively used as anticancer agents in pharmacological applications and also act as polymeric materials [1-3]. In the fluorinated compounds, fluorine plays vital role in medicinal chemistry is considered by number of drugs being prepared in the pharmaceutical fields [4-6]. The hydrogenation of $(\mathrm{CH}=\mathrm{N})$ bond present in Schiff base ligand, form more stable complexes due to enhancing basicity of $\mathrm{N}$ atoms and coordinating properties with metal in reduced Schiff base as compared to their former Schiff base reactants [7].

Reactivity of Schiff base depends upon the electron donor, electron acceptor properties and nature of ligands, when coordination sphere contains binding ability in between ligand to metal [8]. The formation of stable Schiff base complexes contain novel therapeutics and biological applications such as antiviral, antimalarial, antibacterial, anti-fungal and anti-inflammatory in coordination chemistry $[9,10]$. DNA cleavage is an important enzymatic reaction, which concerns in several pharmaceutical and biological processes. The conventional behavioural changes of DNA, when transition metal chelates hold the approaches in the bioinorganic chemistry [11]. Possible high nuclease activity of DNA in reducing environment, may lead to potential binding nature of the compounds [12]. The aim of present work is to synthesis Schiff base metal complexes with ligand N-(4-fluorophenyl)-1-(4-(((4-fluorophenyl)imino)-methyl)phenyl)methaninmine prepared from terephthalaldehyde and 4-fluoroaniline characterized by various spectral techniques.

\section{EXPERIMENTAL}

Terephthalaldehyde, 4-fluoroaniline, hydrated metal(II) chloride, methanol, diethyl ether, dimethyl formamide (DMF), dimethyl sulfoxide (DMSO) were used as analytical grade without further purification purchased from Sigma-Aldrich. The elemental analyses of $\mathrm{C}, \mathrm{H}$ and $\mathrm{N}$ were carried out with a model FLASH 1112 SERIES elemental analyzer. The molar conductance of compounds was measured at room temperature using DMF of concentration $1 \times 10^{-3} \mathrm{M}$. Eletrospray ionization of mass spectra in mode of positive (ESI-MS) was performed

This is an open access journal, and articles are distributed under the terms of the Attribution 4.0 International (CC BY 4.0) License. This license lets others distribute, remix, tweak, and build upon your work, even commercially, as long as they credit the author for the original creation. You must give appropriate credit, provide a link to the license, and indicate if changes were made. 
with a Q-TOF mass spectrometer. The magnetic moment of powdered samples at room temperature was calculated using the Gouy's method with a calibrant $\mathrm{Hg}\left[\mathrm{Co}(\mathrm{SCN})_{4}\right]$. The ${ }^{1} \mathrm{H}$ and ${ }^{13} \mathrm{C}$ NMR $(300 \mathrm{MHz})$ spectrum were carried with Bruker Avance with $\mathrm{CDCl}_{3}$ as solvent and TMS as an internal reference. The FT-IR spectra of complexes were recorded as $\mathrm{KBr}$ pellets using SHIMADZU model spectrometer in range 4000$400 \mathrm{~cm}^{-1}$. The electronic spectral studies were recorded using Lambda Perkin Elemer spectrometer in the range of 200-800 $\mathrm{cm}^{-1}$. The ESR spectrum of X-band in DMSO was obtained at room temperature JES-FA200 (Japan) ESR spectrometer with tetracyano ethylene using as a standard. Thermal analyses were performed with DSC-TGA Universal V4.5A instrument. The temperature range was $30-800^{\circ} \mathrm{C}$ at heating rate of $20^{\circ} \mathrm{C} / \mathrm{min}$ in oxygen atmosphere.

Preparation of ligand (L): The ligand N-(4-fluorophenyl)1-(4-(((4-fluorophenyl)imino)methyl)phenyl)methaninmine has been synthesized by mixing 2:1 ratio of methanolic solution ( $20 \mathrm{~mL}$ ) of 4-fluoroaniline ( $2 \mathrm{mmol}$ ) with terephthalaldehyde ( $1 \mathrm{mmol}$ ) with constant stirring to $4 \mathrm{~h}$ and pale yellow precipitate was obtained. The precipitate was filtered and then washed with methanol followed by diethyl ether, dried in vacuum.

Synthesis of metal(II) chloride complexes: All the metal(II) complexes were synthesized by the following general procedure in 2:1 ratio of ligand with hydrated metal(II) chloride salts. The complexes 1-4 were prepared by the addition of $20 \mathrm{~mL}$ methanol solution $(1 \mathrm{mmol})$ of hydrated metal(II) chlorides with ligand ( $2 \mathrm{mmol}$ ) dissolved in methanol and followed by the addition of two drops of triethylamine. The reacting mixture was stirred and refluxed for $3 \mathrm{~h}$ at $60^{\circ} \mathrm{C}$. The obtained coloured metal complexes were filtered, washed with methanol and followed by diethyl ether and finally dried in vacuum.

DNA cleavage: The efficiency of super helix PUC18DNA cleavage was promoted by the synthesized metal(II) complexes using agarose gel electrophoresis method. The reaction mixture $20 \mu \mathrm{L}$ containing PUC18DNA 50Mm, Tris-HCl, pH 7.4, 52 $\mathrm{Mm}$ of $\mathrm{NaCl}, 10 \mathrm{Mm}$ of $\mathrm{H}_{2} \mathrm{O}_{2}$ were added in a different volume and then adding the millipore water for final volume. The mixed solutions were incubated at $37^{\circ} \mathrm{C}$ for $1 \mathrm{~h}$. After adding $0.5 \mathrm{~g}$ powdered agarose to $50 \mathrm{~mL}$ of buffer solution, it is heated and then cooled, added to ethidium bromide. The gel was examined under ultraviolet light and photographed.

in vitro Antimicrobial activity: in vitro Antibacterial activity of ligand and its mononuclear complexes were screened by $1 \mathrm{~g}$ positive bacteria (Staphylococcus aureus) and gram negative bacteria (Klebsiella pneumoniae) maintained at $4{ }^{\circ} \mathrm{C}$ on nutrient agar slants disc of agar well diffusion method. A $100 \mu \mathrm{L}$ of culture supernatant was loaded into disc and the disc was incubated at $37^{\circ} \mathrm{C}$ for $24 \mathrm{~h}$. The resulting clear inhibition zone was appeared in surrounding surfaces. Standard antibiotic bacteria strain Tetracycline $(10 \mathrm{mg} / \mathrm{mL})$ in DMSO solvent was used. The antifungal activity was tested by the fungi (Candida albicans) in potato dextrose agar medium incubated at $37{ }^{\circ} \mathrm{C}$ for $2-3$ days. Kanamycin $(7.5 \mathrm{mg} / \mathrm{mL})$ in DMSO solvent was used as a standard.

DPPH radical scavenging activity: The free radical scavenging activity of ligand and its metal(II) complexes were measured by using 1,1-diphenyl-2-picryl-hydrazyl (DPPH) assay. The complexes were dissolved in DMSO $(10 \mathrm{mg} / \mathrm{mL})$ and used as stock solutions. From $1 \mathrm{~mL}$ of stock solution at different concentrations were added to $3 \mathrm{~mL}$ of DDPH $(0.004 \%)$ dissolved in DMSO. The mixtures were vortox-mixed and kept at room temperature under dark condition for $30 \mathrm{~min}$. After that the absorbance of complexes (1-4) was taken at $517 \mathrm{~nm}$ using UV-VIS spectrometer with BHA (tert-butyl-4-hydroxyanisole) used as standard and DDPH solution was used as control without complexes. The radical scavenging activity was calculated as percentage of DPPH decolourization by using the following formula:

$$
\text { Scavenging activity }(\%)=\frac{\mathrm{A}_{\mathrm{o}}-\mathrm{A}_{1}}{\mathrm{~A}_{\mathrm{o}}} \times 100
$$

where, $A_{0}$ is the absobance of the control and $A_{1}$ is the absorbance of the sample. The $\mathrm{IC}_{50}$ (concentration of sample required to scavenge $50 \%$ free radical or to prevent lipid peroxidation by $50 \%$ ) was calculated from the regression equation.

\section{RESULTS AND DISCUSSION}

All the synthesized metal complexes 1-4 are coloured powders and stable in air at room temperature. The analytical data of the complexes suggests that all prepared complexes are $\mathrm{M}: 2 \mathrm{~L}$ ratio (Table-1) and have general formula $\mathrm{ML}_{2} \mathrm{Cl}_{2}$ as shown in Scheme-I. All the complexes are insoluble in common organic solvents (methanol, ethanol, chloroform, etc.) and soluble in DMF and DMSO at ambient temperature.

Molar conductance: The conductance of all the metal complexes in DMF $\left(1 \times 10^{-3} \mathrm{M}\right)$ solutions are in the range 5.8$12 \Omega^{-1} \mathrm{~cm}^{-2} \mathrm{~mol}^{-1}$ (Table-1). The resulting low conductance values revealed all the metal complexes are non-electrolytic in nature [13] and indicates that chloride ions are directly coordinated to metal ions [14].

NMR spectra: ${ }^{1} \mathrm{H}$ NMR spectra of Schiff base ligand in $\mathrm{CDCl}_{3}$ exhibited signals of multiplet at $\delta 7.01-7.27 \mathrm{ppm}$ assigned to aryl protons and other aryl proton is observed at $\delta 8.001$ ppm as a singlet [15]. The protons of two imines $(-\mathrm{CH}=\mathrm{N}-)$ group appear as singlet at $\delta 8.50 \mathrm{ppm}$. The structure of ligand is also supported by ${ }^{13} \mathrm{C}$ NMR spectrum. The carbon of imine group exhibited a peak at $\delta 159.09 \mathrm{ppm}$. In ligand, terephthalaldehyde carbon peaks appeared at $\delta 129.1,138.5$ and 115.8-

TABLE-1

PHYSICAL AND ANALYTICAL DATA OF SCHIFF BASE LIGAND (L) AND 1-4 COMPLEXES

\begin{tabular}{|c|c|c|c|c|c|c|c|c|c|}
\hline \multirow{2}{*}{ Compound formula } & \multirow{2}{*}{ Colour } & \multirow{2}{*}{ m.w. } & \multirow{2}{*}{$\begin{array}{l}\text { Yield } \\
(\%)\end{array}$} & \multirow{2}{*}{$\begin{array}{l}\text { m.p. } \\
\left({ }^{\circ} \mathrm{C}\right)\end{array}$} & \multicolumn{4}{|c|}{ Elemental analysis (\%): Calcd. (Found) } & \multirow{2}{*}{$\begin{array}{c}\Lambda_{\mathrm{m}}(\Omega \\
\left.\mathrm{cm}^{2} \mathrm{~mol}^{-1}\right)\end{array}$} \\
\hline & & & & & $\mathrm{C}$ & $\mathrm{H}$ & $\mathrm{N}$ & $\mathrm{Cl}$ & \\
\hline $\mathrm{C}_{20} \mathrm{H}_{14} \mathrm{~F}_{2} \mathrm{~N}_{2}(\mathbf{L})$ & Pale-yellow & 320.10 & 80 & 190 & $74.82(74.99)$ & $4.01(4.41)$ & $11.86(11.21)$ & - & - \\
\hline $\mathrm{CoC}_{40} \mathrm{H}_{28} \mathrm{~F}_{4} \mathrm{~N}_{4} \mathrm{Cl}_{2}(\mathbf{1})$ & Pale-green & 770.06 & 70 & 290 & $62.35(61.64)$ & $3.67(3.72)$ & $7.28(7.53)$ & $9.21(9.34)$ & 4.2 \\
\hline $\mathrm{NiC}_{40} \mathrm{H}_{28} \mathrm{~F}_{4} \mathrm{~N}_{4} \mathrm{Cl}_{2}(\mathbf{2})$ & Pale-green & 769.82 & 68 & 245 & $62.33(62.01)$ & $3.66(3.37)$ & $7.27(7.31)$ & $9.21(8.91)$ & 8.1 \\
\hline $\mathrm{CuC}_{40} \mathrm{H}_{28} \mathrm{~F}_{4} \mathrm{~N}_{4} \mathrm{Cl}_{2}(\mathbf{3})$ & Black & 774.68 & 75 & 294 & $61.96(59.97)$ & $3.67(3.91)$ & $7.23(7.64)$ & $9.15(8.75)$ & 5.8 \\
\hline $\mathrm{ZnC}_{40} \mathrm{H}_{28} \mathrm{~F}_{4} \mathrm{~N}_{4} \mathrm{Cl}_{2}(4)$ & Dirty-yellow & 776.54 & 65 & 267 & $61.81(60.94)$ & $3.63(3.21)$ & $7.21(7.14)$ & $9.13(9.29)$ & 3.2 \\
\hline
\end{tabular}




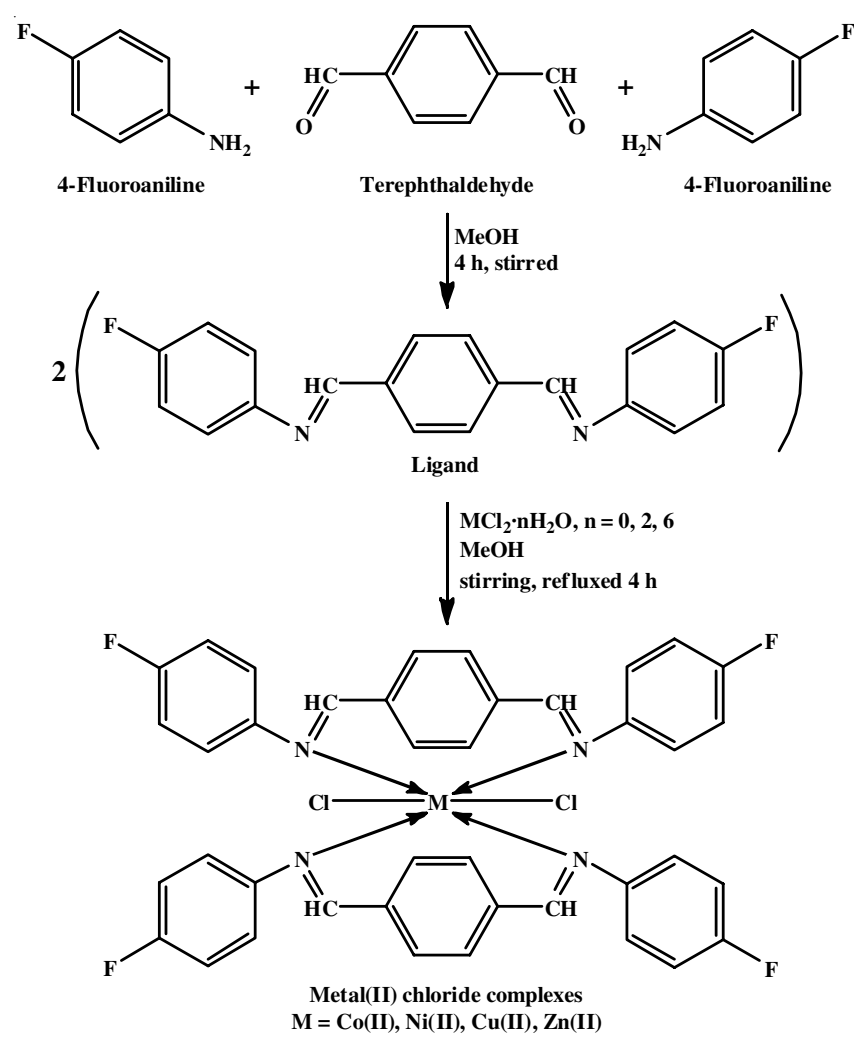

Scheme-I: Synthesis of ligand and proposed structure of metal(II) complexes

122.5 ppm peaks are due to carbon of substituted aniline. The last singlet peak recorded at $\delta 163.1 \mathrm{ppm}$ is due to fluorine substituted carbon of aniline in the ligand.

ESI-Mass spectra: The stoichiometric composition of ligand and its metal complex 3 was determined using ESI mass spectrum. The molecular ion peak of ligand $\mathrm{M}^{+}$observed at $\mathrm{m} / \mathrm{z}=320.7 \mathrm{amu}$ and various fragmentation (L) peaks appeared at 320.7, 227.8, 216.8, 111.9 amu (Fig. 1a). This observed molecular ion peak confirms the formula of ligand $\left(\mathrm{C}_{20} \mathrm{H}_{14} \mathrm{~N}_{2} \mathrm{~F}_{2}\right)$. The complex 3 exhibited the molecular ion peak at $\left(\mathrm{M}^{+}+2 \mathrm{H}\right)$ which is coincident with $m / z=776.3$ amu value. The various fragmentations showed the thermal stability of complex. This value was further supported by other synthesized complexes of mass spectra (Fig. 1b).
Electronic spectra and magnetic moments: The electronic spectrum of ligand exhibited three bands (intra-ligand) at 243, 293 and $350 \mathrm{~nm}$. The first two bands are assigned to $\pi \rightarrow \pi^{*}$ transition and final band at $350 \mathrm{~nm}$ is assigned to $\mathrm{n} \rightarrow \pi^{*}$ transition [16]. The charge transfer $(\mathrm{L} \rightarrow \mathrm{M})$ transitions of complexes displayed between $371-413 \mathrm{~nm}$ is due to ligand coordinated to metal(II) ion. The complex 1 displayed $d$-d transitions of weak band at $608 \mathrm{~nm}$ and broad band at $672 \mathrm{~nm}$ with $\mathrm{T}_{1 \mathrm{~g}} \rightarrow \mathrm{A}_{2 \mathrm{~g}}(\mathrm{~F})$ and ${ }^{4} \mathrm{~T}_{1 \mathrm{~g}} \rightarrow{ }^{4} \mathrm{~T}_{2 \mathrm{~g}}(\mathrm{~F})$ transitions respectively. The magnetic moment value 4.7 B.M. which confirm that complex 1 possess a regular octahedral geometry [17]. The electronic absorption spectra of complex 2 attributed medium bands at 556 and $702 \mathrm{~nm}$ which may assign to ${ }^{3} \mathrm{~A}_{2 \mathrm{~g}}(\mathrm{~F}) \rightarrow{ }^{3} \mathrm{~T}_{1 \mathrm{~g}}$ $(\mathrm{P})$ and ${ }^{3} \mathrm{~A}_{2 \mathrm{~g}}(\mathrm{~F}) \rightarrow{ }^{3} \mathrm{~T}_{1 \mathrm{~g}}(\mathrm{~F})$, respectively. The magnetic moment of complex is 2.6 B.M, which is an evidence of octahedral environs around the Ni(II) ions [18]. The complex 3 exhibits a broad band at $573 \mathrm{~nm}$ and a medium band at $751 \mathrm{~nm}$ which is due to ${ }^{2} \mathrm{E}_{\mathrm{g}} \rightarrow{ }^{2} \mathrm{~T}_{2 \mathrm{~g}}$ and ${ }^{2} \mathrm{~B}_{1 \mathrm{~g}} \rightarrow{ }^{2} \mathrm{~A}_{2 \mathrm{~g}}$ transitions, respectively. The magnetic measurement value is 1.87 B.M and this may be given a distorted octahedral stoichiomery of $\mathrm{Cu}$ (II) complex [19]. The diamagnetic nature of complex $\mathbf{4}$ shows the charge transfer transitions and has no $d$ - $d$ absorptions, probably due to an octahedral geometry.

FTIR spectra: The sharp band appeared at $1620 \mathrm{~cm}^{-1}$ is due to the stretching vibration of azomethine $(-\mathrm{CH}=\mathrm{N}-)$ group of Schiff base ligand [20]. For all the synthesized metal complexes 1-4, the intensity of absorption bands at $1622-1618 \mathrm{~cm}^{-1}$ is shifted to lower or higher wavelengths indicates formation of (M-N) coordination. This is further confirmed with small intensity bands exhibited at $428-413 \mathrm{~cm}^{-1}$ of (M-N) vibrations [21]. The stretching vibrations of $(-\mathrm{C}=\mathrm{C}-)$ aromatic ring in ligand appears as medium intensity band at $1594 \mathrm{~cm}^{-1}$ [22]. These vibrations shifted to lower wavelengths by $11-86 \mathrm{~cm}^{-1}$ for all the complexes 1-4 when compared to ligand.

ESR spectra: The ESR spectrum of X-band of polycrystalline solid complex $\mathbf{3}$ was recorded in powder form at room temperature $(77 \mathrm{~K})$ in DMSO solution. It exhibits g-tensor parameter $g_{\|}(2.21)>g_{\perp}(2.15)>g_{e}(2.002)$ which indicates that the complex $\mathbf{3}$ has an unpaired electron present in $\mathrm{d}_{\mathrm{x}^{2}-\mathrm{y}^{2}}$ ground state [23]. This complex displayed that the spectra is axially symmetrical with no hyperfine splitting. Commonly

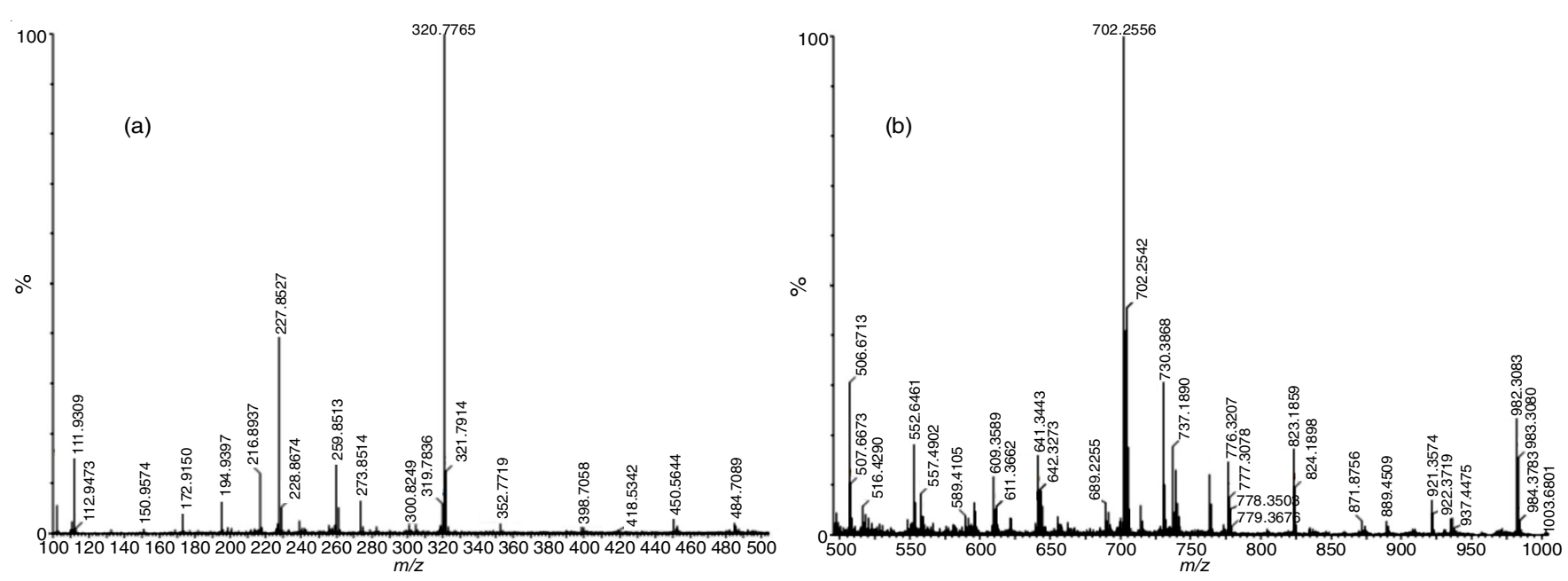

Fig. 1. Mass spectra (a) ligand $\mathbf{L}$ (b) $\mathrm{Cu}$ (II) complex 
six coordinated complex 3 displayed high $\mathrm{g}_{\|}$value with ligand having $\mathrm{N}$ and $\mathrm{O}$ hard donors [24]. It concluded that the presented complex have high $\mathrm{g}_{\|}$value of four $\mathrm{N}$ donors sites, which consist of a six coordinated complex $\mathbf{3}$ has a distorted octahedral $\mathrm{Cu}$ (II) ion. The $\mathrm{G}$ value is calculated following expression $\mathrm{G}=\left(\mathrm{g}_{\|}-\right.$ $2.002) /\left(g_{\perp}-2.002\right)$, where $G$ measures the considerable exchange interaction of copper centre ion in the polycrystalline compound. The $g_{a v}$ is also calculated by the following relation $g_{a v}=1 / 3\left(g_{\|}\right.$ $\left.+2 g_{\perp}\right)$. The $g_{\|}$value also predicts the ionic and covalent environment in metal-ligand bond. The $\mathrm{g}_{\|}$value is less than 2.3 which indicates the covalent nature present in metal-ligand bonding [25].

Thermal analysis: The ligand decomposed completely without impurity at $347^{\circ} \mathrm{C}$, with loss of weight $100 \%$ (calc. $100 \%$ ). Decomposition of ligand is single stage process. All the metal complexes of decomposition takes places in three degradation stages. The synthesized metal complexes 1-4, first stage start decomposing at $73-169^{\circ} \mathrm{C}$ with a weight loss of 9.13-9.21\%. This is in good agreement with the calculated (9.13-9.21\%) values and the percentage of weight indicating the loss of two chlorine atoms in the coordination sphere [26].

Thermal decomposition of complex 1 consisted temperature range $161-347{ }^{\circ} \mathrm{C}$ corresponded by mass loss of $51.30 \%$, which is in good results with calculated $(51.74 \%$ ) values and contributed to loss of $\mathrm{C}_{24} \mathrm{H}_{16} \mathrm{~N}_{2} \mathrm{~F}_{2}$ moiety. The third stage decomposition occurs from $345-644^{\circ} \mathrm{C}$ by a weight loss of $20.42 \%$. It is good agreement with the calculated $(20.55 \%)$ value by assigned to removal of $\mathrm{C}_{9} \mathrm{H}_{10}+2 \mathrm{HF}$ moiety and the remaining product $5 \mathrm{C}+\mathrm{CoO}$ as a residue. For complex 2, second stage thermal decomposition occurs at $162-339^{\circ} \mathrm{C}$, which corresponds to the loss of $\mathrm{C}_{24} \mathrm{H}_{16} \mathrm{~N}_{4} \mathrm{~F}_{4}$ organic moiety. The weight loss of $(55.81 \%)$ is in good agreement with calculated (56.65 $\%$ ) value. The third stage starts at $339-700^{\circ} \mathrm{C}$ assigned by weight loss of $19.12 \%$, which is related to calculated $(19.32 \%)$ value corresponding to elimination of $\mathrm{C}_{10} \mathrm{H}_{12}$ and the final residue was $6 \mathrm{C}+\mathrm{NiO}$ (Fig. 2).

The second stage thermal decomposition of complex 3 occurs at $169-302^{\circ} \mathrm{C}$, which attributed to the weight loss of $52.88 \%$ and related to calculated $(53.65 \%)$ value with a removal of $\mathrm{C}_{24} \mathrm{H}_{16} \mathrm{~N}_{4} \mathrm{~F}_{3}$ organic moiety. The third stage occurs at 302 $655^{\circ} \mathrm{C}$, assigned to weight loss of $15.21 \%$ is due to the loss of $\mathrm{C}_{7} \mathrm{H}_{11}+\mathrm{HF}$, which is good results for calculated (14.89\%) value

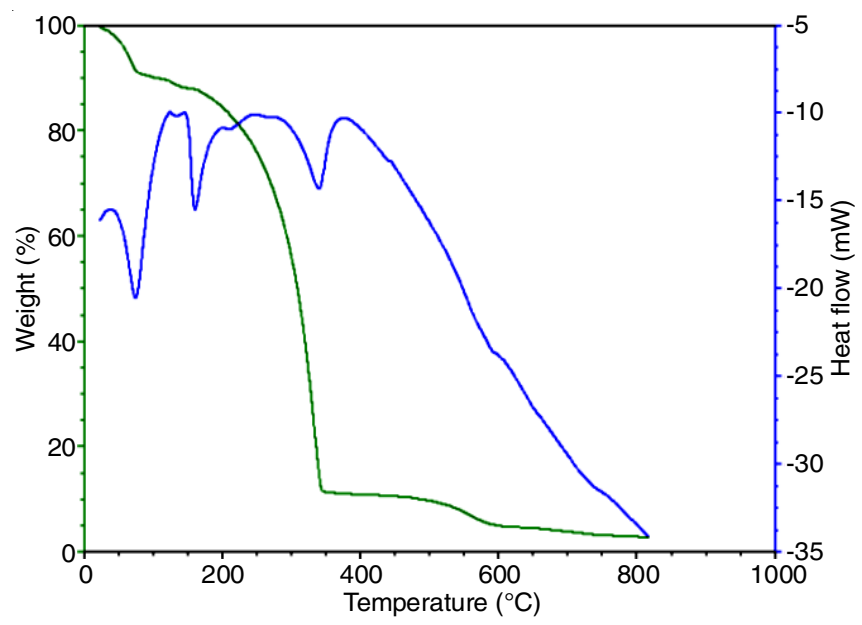

Fig. 2. DSC-TGA curve for complex 2 and the final product $9 \mathrm{C}+\mathrm{CuO}$ as a residue [27]. The second stage of thermal decomposition in complex 4 exhibited at 167$341^{\circ} \mathrm{C}$ accompanied by the weight loss of $55.52 \%$, which is good agreement with calculated (56.02\%) value. The organic moiety of $\mathrm{C}_{24} \mathrm{H}_{16} \mathrm{~N}_{4} \mathrm{~F}_{4}$ was lost. Decomposition occurs in third stage at $341-668^{\circ} \mathrm{C}$, which contributed by loss of $\mathrm{C}_{10} \mathrm{H}_{12}$ organic moiety with weight loss of $17.04 \%$ and calculated (16.44\%) value. The final residue was $6 \mathrm{C}+\mathrm{ZnO}$. From elemental analysis data and thermal analysis curves related to confirm the structure of ligand and complexes.

DNA Cleavage: DNA cleavages of agarose gel electrophoresis method were performed against PUC18DNA with metal complexes on basis of oxidative mechanisms in being of hydrogen peroxide. DNA cleavage was presided by relaxation of the super helix (plasmid) form of PUC18DNA (Form I) into open circular form (Form II) and linear form (Form III). In Fig. 3, complex 3 cleavage activity showed good efficiency and conversion of open circular form (Form II) to linear form (Form III) with increasing in concentrations (30 and $40 \mu \mathrm{M}$ ) (lane 3,4 ) due to hydroxyl radical $\left({ }^{\circ} \mathrm{OH}\right)$, which cause damage to the sugar or base of DNA. In complexes $\mathbf{2}$ and $\mathbf{4}$, the nuclease activity with super helix DNA (Form I) changed to open circular form (Form II) (lane 7, 9). Owing to increasing in concentrations, cleaving activity also increases (lane 8,10 ). The complex 3 was completely degraded with DNA (lane 5,6 ) due to presence of empty reducible metal centre make it inactive towards the hydroxyl radicals. The control DNA alone (lane 1) and with hydrogen peroxide (lane 2) having no cleaving activity. From this, concluded all the synthesized complexes 1-4 retard the growth of pathogenic organism by cleaving the genome [28].
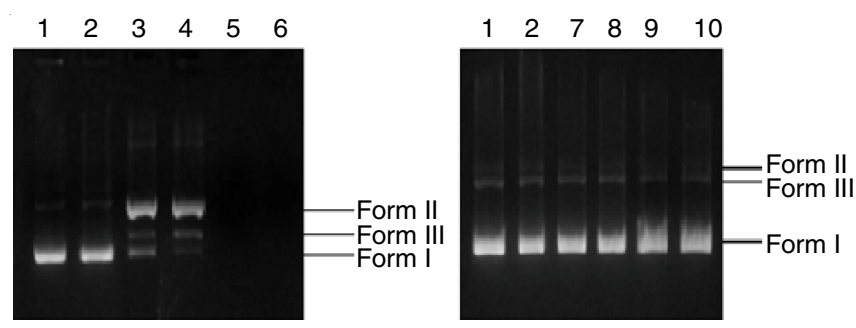

Fig. 3. Agarose-gel electrophoresis method of DNA cleavage of metal complexes in DMSO of various concentrations. Lane 1: PUC18 DNA control; Lane 2: DNA $+\mathrm{H}_{2} \mathrm{O}_{2}(1 \mathrm{mM})$; Lane 3: DNA $+\mathrm{H}_{2} \mathrm{O}_{2}$ $(1 \mathrm{mM})+\mathrm{Cu}(30 \mu \mathrm{M}) ;$ Lane $4:$ DNA $+\mathrm{H}_{2} \mathrm{O}_{2}(1 \mathrm{mM})+\mathrm{Cu}(40 \mu \mathrm{M})$; Lane 5: DNA $+\mathrm{H}_{2} \mathrm{O}_{2}(1 \mathrm{mM})+\mathrm{Co}(30 \mu \mathrm{M})$; Lane 6: DNA $+\mathrm{H}_{2} \mathrm{O}_{2}$ $(1 \mathrm{mM})+\mathrm{Co}(40 \mu \mathrm{M}) ;$ Lane $7: \mathrm{DNA}+\mathrm{H}_{2} \mathrm{O}_{2}(1 \mathrm{mM})+\mathrm{Ni}(30 \mu \mathrm{M})$; Lane 8: DNA $+\mathrm{H}_{2} \mathrm{O}_{2}(1 \mathrm{mM})+\mathrm{Ni}(40 \mu \mathrm{M})$; Lane 9: DNA $+\mathrm{H}_{2} \mathrm{O}_{2}$ $(1 \mathrm{mM})+\mathrm{Zn}(30 \mu \mathrm{M}) ;$ Lane 10: DNA $+\mathrm{H}_{2} \mathrm{O}_{2}(1 \mathrm{mM})+\mathrm{Zn}(40 \mu \mathrm{M})$

Antimicrobial activity: The synthesized Schiff base ligand and its metal complexes were tested aganist gram positive $S$. aureus and gram negative $K$. pneumoniae bacterial strains with Tetracycline is used as a standard. All the complexes have shown greater activity than ligand results as given in Table- 2 . This is explained on the chelating theory [29] and Overton's concept [30]. From this concept mainly noticed that cell permeability and lipophilic character of compound. Owing to cell permeability, the cell is covered by lipid membrane and it allows only lipid soluble compounds, to pass through it. According to lipophilic character, the polarity of metal ion changes positive charge, due to formation of donor group. Cell permeability 
TABLE-2

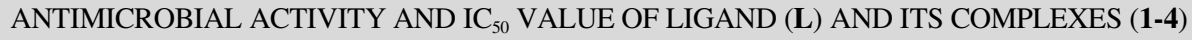

\begin{tabular}{|c|c|c|c|c|}
\hline \multirow{3}{*}{ Compound } & \multicolumn{3}{|c|}{ Zone of inhibition (mm) in $100 \mu \mathrm{L}$ concentration } & \multirow{3}{*}{$\mathrm{IC}_{50}(\mu \mathrm{g} / \mathrm{mL})$} \\
\hline & \multicolumn{2}{|c|}{ Bacterial activity } & \multirow{2}{*}{$\begin{array}{c}\text { Fungal activity } \\
\text { C. albicans }\end{array}$} & \\
\hline & S. aureus & K. pneumoniae & & \\
\hline $\mathrm{C}_{20} \mathrm{H}_{14} \mathrm{~F}_{2} \mathrm{~N}_{2}(\mathbf{L})$ & - & - & 9 & 0.176 \\
\hline $\mathrm{CoC}_{40} \mathrm{H}_{28} \mathrm{~F}_{4} \mathrm{~N}_{4} \mathrm{Cl}_{2}(\mathbf{1})$ & 7 & 11 & 14 & 0.147 \\
\hline $\mathrm{NiC}_{40} \mathrm{H}_{28} \mathrm{~F}_{4} \mathrm{~N}_{4} \mathrm{Cl}_{2}(2)$ & 7 & 9 & 11 & 0.121 \\
\hline $\mathrm{CuC}_{40} \mathrm{H}_{28} \mathrm{~F}_{4} \mathrm{~N}_{4} \mathrm{Cl}_{2}(\mathbf{3})$ & 9 & 10 & 11 & 0.114 \\
\hline $\mathrm{ZnC}_{40} \mathrm{H}_{28} \mathrm{~F}_{4} \mathrm{~N}_{4} \mathrm{Cl}_{2}(4)$ & 7 & - & 10 & 0.140 \\
\hline Tetracycline $(10 \mathrm{mg} / \mathrm{ml})$ & 16 & 19 & - & - \\
\hline Kanamycin $(7.5 \mathrm{mg} / \mathrm{ml})$ & - & - & 16 & - \\
\hline tert-Butyl-4-hydroxyanisole (BHA) & - & - & - & 0.127 \\
\hline
\end{tabular}

increase with lipophilic character, penetrates the complexes more efficient activity by killed micro-organisms.

Among these two bacteria's, gram negative bacteria strain shows more activity than gram positive bacteria. In complex 3, S. aureus has greater activity than other complexes. The complexes 1, 2 and $\mathbf{4}$ exhibited in nearly too moderate activity. Antifungal activity was determined against fungai strain Candida albcians, kanamycin using as a standard. All the synthesized complexes shown excellent activity, except complex 4 which has medium activity. The complex $\mathbf{1}$ has more activity, nearest to standard (kanamycin).

DPPH radical scavenging activity: The DPPH radical scavenging activity is highly considered reliable method to quantify the antioxidant activities of compounds. The antioxidants donate hydrogen to free radical DPPH, leading to non-toxic species and therefore to inhibition of the propagation phase of lipid oxidation. So absorbance decreases indicates the higher free radical scavenging activity was expressed for $\mathrm{IC}_{50}$ values (Table-2) [31]. The $\mathrm{IC}_{50}$ value is inversely related to the radical scavenging activity. The $\mathrm{Cu}$ (II) and $\mathrm{Ni}$ (II) complexes showed efficient scavenging activity when compared to BHA as standard. The $\mathrm{Co}(\mathrm{II})$ and $\mathrm{Zn}$ (II) complexes showed the moderate antioxidant activity and the prominent activity showed by ligand. The DPPH radical scavenging activity of complexes may depends on formation of metal ion chelation of complexes.

\section{Conclusion}

Newly synthesized Schiff base (L) ligand and its transition mononuclear complexes 1-4 were characterized by various spectral methods. The composition of all the metal complexes is confirmed by molar conductance, elemental analysis, mass, ESR spectral studies. The electronic and IR spectrum suggested the bidentate coordination of ligand with the transition metal(II) ions. The stability of ligand and its metal complexes were determined with the help of DSC-TGA thermal analysis. DNA cleavage activity revealed that complex $\mathbf{3}$ has good efficiency than the other complexes. Fluorinated aniline group in this complex may responsible for the kind potential copper drugs in reducing environment. All prepared metal complexes are bioactive against bacterial strains and fungal strain whereas complex 4 is inactive against $K$. pneumoniae.

\section{CONFLICT OF INTEREST}

The authors declare that there is no conflict of interests regarding the publication of this article.

\section{REFERENCES}

1. T.S. Basu Baul, I. Longkumer, A. Duthie, P. Singh, B. Koch, and M.F.C. Guedes Da Silva, Dalton Trans., 47, 1993 (2018); https://doi.org/10.1039/c7dt04037g.

2. J. Kumar, A. Rai and V. Raj, Org. Med. Chem., 1, 555 (2017).

3. M. Kurt, M. Yurdakul and S. Yurdakul, J. Mol. Struct. THEOCHEM, 711, 25 (2004);

https://doi.org/10.1016/j.theochem.2004.07.034.

4. A. Palumbo Piccionello, R. Musumeci, C. Cocuzza, C.G. Fortuna, A. Guarcello, P. Pierro and A. Pace, Eur. J. Med. Chem., 50, 441 (2012); https://doi.org/10.1016/j.ejmech.2012.02.002.

5. R.A. Tucaliuc, V.V. Cotea, M. Niculaua, C. Tuchilus, D. Mantu and I.I. Mangalagiu, Eur. J. Med. Chem., 67, 367 (2013); https://doi.org/10.1016/j.ejmech.2013.04.069.

6. G. Pattison, G. Sandford, D.S. Yufit, J.A.K. Howard, J.A. Christopher and D.D. Miller, Tetrahedron, 65, 8844 (2009); https://doi.org/10.1016/j.tet.2009.08.050.

7. S. Shukla and A.P. Mishra, Arab. J. Chem., (2014); https://doi.org/10.1016/j.arabjc.2014.08.020.

8. M. Usharani, E. Akila, S. Ramachandran, G. Velraj and R. Rajavel, Int. J. Pharm. Pharm. Sci., 5, 639 (2013).

9. A.M. Abu-Dief and I.M.A. Mohamed, Beni-Suef Univ. J. Basic Appl. Sci., 4, 119 (2015); https://doi.org/10.1016/j.bjbas.2015.05.004.

10. S. Vedanayaki and P. Jayaseelan, Eur. J. Chem., 7, 368 (2016); https://doi.org/10.5155/eurjchem.7.3.368-374.1443.

11. P. Jayaseelan, E. Akila, M. Usha Rani and R. Rajavel, J. Saudi Chem. Soc., 20, 625 (2016); https://doi.org/10.1016/j.jscs.2013.07.001.

12. A. Jana, P. Brandão, G. Mondal, P. Bera, A. Santra, A.D. Jana, R.B. Mokhamatam, S.K. Manna, N. Bhattacharyya and P. Bera, Inorg. Chim. Acta, 482, 621 (2018);

https://doi.org/10.1016/j.ica.2018.06.054.

13. W.J. Geary, Coord. Chem. Rev., 7, 81 (1971); https://doi.org/10.1016/S0010-8545(00)80009-0.

14. S. Amer, N. El-Wakiel and H. El-Ghamry, J. Mol. Struct., 1049, 326 (2013); https://doi.org/10.1016/j.molstruc.2013.06.059.

15. A.A. Dar, A. Mallick and R. Murugavel, New J. Chem., 39, 1186 (2015); https://doi.org/10.1039/C4NJ01614A.

16. G. Ramesh, M. P. Kumar, A. Rambabu, N. Vamsikrishna and S. Daravath, Asian J. Chem. Sci., 4, 1 (2018).

17. S.M. Emam, S.A.A. El-Enein and E.M. Emara, J. Therm. Anal. Calorim., 127, 1611 (2017); https://doi.org/10.1007/s10973-016-5835-6.

18. P. Sikarwar, S. Tomar and A. P. Singh, Am. J. Chem., 6, 119 (2016); https://doi.org/10.5923/j.chemistry.20160605.02.

19. A.P. Mishra, R.K. Mishra and S.P. Shrivastava, J. Serbian Chem. Soc., 74, 523 (2009); https://doi.org/10.2298/JSC0905523M.

20. P. Gull and A.A. Hashmi, J. Braz. Chem. Soc., 26, 1331 (2015); https://doi.org/10.5935/0103-5053.20150099.

21. R.R. Amin, A.A.M. El-Reedy, T.Y. Alansi and Y.B. Yamany, Open J. Inorg. Chem., 6, 89 (2016); https://doi.org/10.4236/ojic.2016.62006. 
22. S. Baluja, S. Chanda, and N. Godvani, Pharm. Chem. J., 48, 797 (2015); https://doi.org/10.1007/s11094-015-1198-8.

23. B.J. Hathaway and D.E. Billing, Coord. Chem. Rev., 5, 143 (1970); https://doi.org/10.1016/S0010-8545(00)80135-6.

24. F. Rafat, M.Y. Siddiqi and K.S. Siddiqi, J. Serbian Chem. Soc., 69 , 641 (2004); https://doi.org/10.2298/JSC0409641R.

25. A. Prakash and R. Malhotra, Appl. Organomet. Chem., 32, e4098 (2018); https://doi.org/10.1002/aoc.4098.

26. P. Jayaseelan, S. Prasad, S. Vedanayaki and R. Rajavel, Arab. J. Chem., 9, S668 (2016); https://doi.org/10.1016/j.arabjc.2011.07.029.

27. W.A. Zordok and S.A. Sadeek, J. Therm. Anal. Calorim., 128, 971 (2017);

https://doi.org/10.1007/s10973-016-5979-4.
28. A. Kulkarni, S.A. Patil and P.S. Badami, Eur. J. Med. Chem., 44, 2904 (2009);

https://doi.org/10.1016/j.ejmech.2008.12.012.

29. Y. Anjaneyulu and R.P. Rao, Synth. React. Inorg. Met. Chem., 16, 257 (1986);

https://doi.org/10.1080/00945718608057530.

30. R.N. Patel, S.P. Rawat and M. Choudhary, Int. J. Inorg. Chem., 2013, Article ID 617837 (2013); https://doi.org/10.1155/2013/617837.

31. P. Kavitha, M. Rama Chary, B.V.V.A. Singavarapu and K. Laxma Reddy, J. Saudi Chem. Soc., 20, 69 (2016); https://doi.org/10.1016/j.jscs.2013.03.005. 